\title{
A review of Dichorrhinus Desbrochers, 1875 (Coleoptera, Curculionidae) with two new species from Greece and Turkey, and from Cyprus
}

\author{
Christoph GERMANN \\ Naturhistorisches Museum der Burgergemeinde Bern, Bernastrasse 15, CH-3005 Bern \\ and Natur-Museum Luzern, Kasernenplatz 6, CH-6003 Lucerne, Switzerland \\ E-mail: germann.christoph@gmail.com \\ urn:lsid:zoobank.org:author:0FFE5732-6AE7-4857-B837-54D30F41F573
}

\begin{abstract}
The species of the Eastern Mediterranean genus Dichorrhinus Desbrochers, 1875 are reviewed. D. geiseri sp. nov. is described from Samos Island (Greece) and Western Turkey, and D. alziari sp. nov. is described from Cyprus. Dichorrhinus korbi Schilsky, 1911 is redescribed. An illustrated key to the species of Dichorrhinus is provided, and new records are presented.
\end{abstract}

Keywords. Entiminae, Phyllobiini, new species, redescription, taxonomy.

Germann C. 2013. A review of Dichorrhinus Desbrochers, 1875 (Coleoptera, Curculionidae) with two new species from Greece and Turkey, and from Cyprus. European Journal of Taxonomy 46: 1-13. http://dx.doi.org/10.5852/ ejt.2013.46

\section{Introduction}

The genus Dichorrhinus was described by Desbrochers (1875) with its type species D. pseudoscythropus Desbrochers, 1875 from a locality nowadays situated in Lebanon. Presently, Dichorrhinus comprises four species: D. pseudoscythropus from Lebanon and Syria, D. creticus (Faust, 1889) from Crete, Greece, D. freyi F. Solari, 1940 from Libya and D. korbi Schilsky, 1911 from Turkey. All species are characterised by the unique shape of their rostrum, which has a bright, glabrous and shiny nasal plate.

The genera most similar to Dichorrhinus, concerning their habitus and rostrum with a glabrous nasal plate, are Parascythopus Desbrochers, 1875 (Phyllobiini) and Pachyrhinus Schönherr, 1823 (Polydrusini), where especially Pachyrhinus lethierryi (Desbrochers, 1875) can be confused with a Dichorrhinus at first sight based on a similar habitus, although the scrobes are laterally open in Pachyrhinus. It was Solari (1940) who proposed placing Dichorrhinus in Phyllobiini, based on the dorsally open antennal scrobes, followed by Pesarini (1980) and Alonso-Zarazaga \& Lyal (1999). The last review of Dichorrhinus was included in Pesarini's survey of Phyllobiini (1980). The entirely glabrous and shiny nasal plate of the rostrum allows a reliable separation of Dichorrhinus and Parascythopus from Phyllobius Germar, 1824, and Dichorrhinus differs from Parascythopus in the broader, roundish scales (piliform and acuminate in Parascythopus) and the elevated glabrous surface of the nasal plate, well separated towards the base of the rostrum (not elevated and indistinctly separated in Parascythopus). 
The present review of Dichorrhinus was initiated after the collection of new specimens in Greece, Turkey, Syria and Cyprus. The examination of these specimens led to the discovery of D. geiseri sp. nov. from Western Turkey and Greece. The comparison of specimens collected in Syria and Cyprus revealed that the latter belong to another unnamed species, D. alziari sp. nov., described below. Specimens from Cyprus have generally been regarded as D. pseudoscythropus, described by Desbrochers (1875) from Djebel Baalbek in Lebanon (Winkler 1924-1932; Solari 1940; Pesarini 1980; Alziar 1995, 2003, 2012). This series of misidentifications was started by Desbrochers himself (1902a, b), when he provided a redescription of the genus Dichorrhinus and its type species D. pseudoscythropus (1902b: 151-152), indicating "Chypre" as provenance.

Furthermore, a larger series of Dichorrhinus korbi, collected in Turkey, and the examination of the holotype allowed this species to be redescribed.

\title{
Material and methods
}

Photographs were taken with a 5-megapixel digital camera (Leica DFC 420). Series of images were captured through a binocular microscope (Leica MZ16) and processed through Auto-Montage software (Imagic Image Access, Version 8).

All measurements were taken digitally with the measurement-tool of the above mentioned Auto-Montage software. Body length was measured from the anterior margin of the eye to the apex of the elytra.

\author{
Abbreviations \\ $\mathrm{NMB}=$ Naturhistorisches Museum Basel \\ NMBE $=$ Naturhistorisches Museum der Burgergemeinde Bern \\ MFN = Museum für Naturkunde, Berlin \\ SDEI = Senckenberg Deutsches Entomologisches Institut, Müncheberg \\ $\mathrm{cGA}=$ collection of Gabriel Alziar (France, Cassagnes-Bégonhès) \\ $\mathrm{cJL}=$ collection of Jean-Michel Lemaire (France, Contes) \\ $\mathrm{cJP}=$ collection of Jean Pelletier (France, Monnaie) \\ $\mathrm{cRB}=$ collection of Roman Borovec (Czech Republic, Sloupno) \\ $\mathrm{cSB}=$ collection of Stanislav Benedikt (Czech Republic, Plzeň) \\ $\mathrm{cPB}=$ collection of Piotr Białooki (Poland, Gdynia)
}

Labels are cited in full from the top downward, with data from each label enclosed in quotation marks. Labels are cited with original spelling and punctuation. Different labels are separated by double slash marks (//). Additional information is included in square brackets. 


\title{
Results
}

\author{
Class Hexapoda Blainville, 1816 \\ Order Coleoptera Linné, 1758 \\ Superfamily Curculionoidea Latreille, 1802 \\ Family Curculionidae Latreille, 1802 \\ Subfamily Entiminae Schönherr, 1826 \\ Tribe Phyllobiini Schönherr, 1826 \\ Genus Dichorrhinus Desbrochers, 1875 \\ Dichorrhinus geiseri sp. nov. \\ urn:1sid:zoobank.org:act:0B6748F9-8B14-4690-B641-2DFF11ED3607
}

Figs $1 \mathrm{C}, \mathrm{H}, 2 \mathrm{~A}-\mathrm{F}, \mathrm{T}$

\section{Etymology}

The new species is dedicated to Michael Geiser (Basel), expert in Prionoceridae and dear colleague. The chance to examine his collection of weevil specimens from Samos-Island initiated the present review.

\section{Type material}

\section{Holotype}

§, “Griechenland SAMOS Limnionas env. [environment] $37^{\circ} 41^{\prime} \mathrm{N} / 26^{\circ} 37^{\prime} \mathrm{E}$ M. Geiser leg. 23.III.2008”// "Macchia, Klopfschirm [beating tray]". Red label: "Holotype Dichorrhinus geiseri sp. nov. C. Germann des. 2013" (NMBE).

\section{Paratypes}

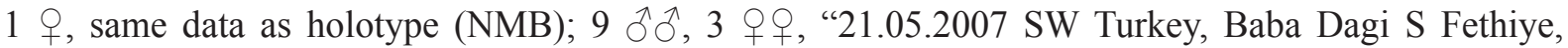
leg. P. Białooki”; 7 ふ઼へ, 10 우, “19.05.2007 SW Turkey, Baba Dagi SW Denizli, leg. P. Białooki”;

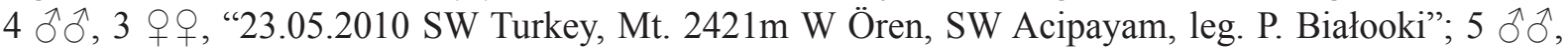
6 우, “25.05.2007 SW Turkey, Ak Dagi W Aglasun, S Isparta, leg. P. Białooki” (NMBE, cPB). All 48 paratypes are additionally labelled with red paper: "Paratype Dichorrhinus geiseri sp. nov. C. Germann des. 2013".

\section{Description}

Size. (Without rostrum) males $4.2 \mathrm{~mm}(3.8-4.7 \mathrm{~mm})$, females $4.7 \mathrm{~mm}(4.4-5.1 \mathrm{~mm})$.

Colour. Body, head and femora dark brown to black; nasal plate, antennae, tips of femora, partly tibiae and all tarsal segments reddish-brown.

HEAD. Eyes strongly convex, protruding, short oval in section. Rostrum about as long as wide, with well separated, glabrous and reddish-brown nasal plate; glossy from rostral dorsum to the scrobes. From there to epistome punctuate-striate. Head and basal half of rostrum with oval, green-metallic scales and long, partly bowed, dark hairs. Antennae reddish brown, apex of scape and club slightly darker. Antennal scape long, bowed and slender, reaching fore margin of pronotum. Apex of scape thickened, three times wider than base. Seven segments of antennal funiculus as follows (L/W): 1: 3.2, 2: 3.5, 3: $2.1,4^{\text {th }}$ and $5^{\text {th }} 1.9,6: 1.4,7: 1.5$. Club fusiform, long and slender.

Pronotum. (L/W): 0.7, transverse, widest in the middle, strongly constricted just before fore margin, sides rounded. Densely and irregularly punctuate on disc, vestiture consisting of oval, metallic green scales and long, dark, bowed hairs. 

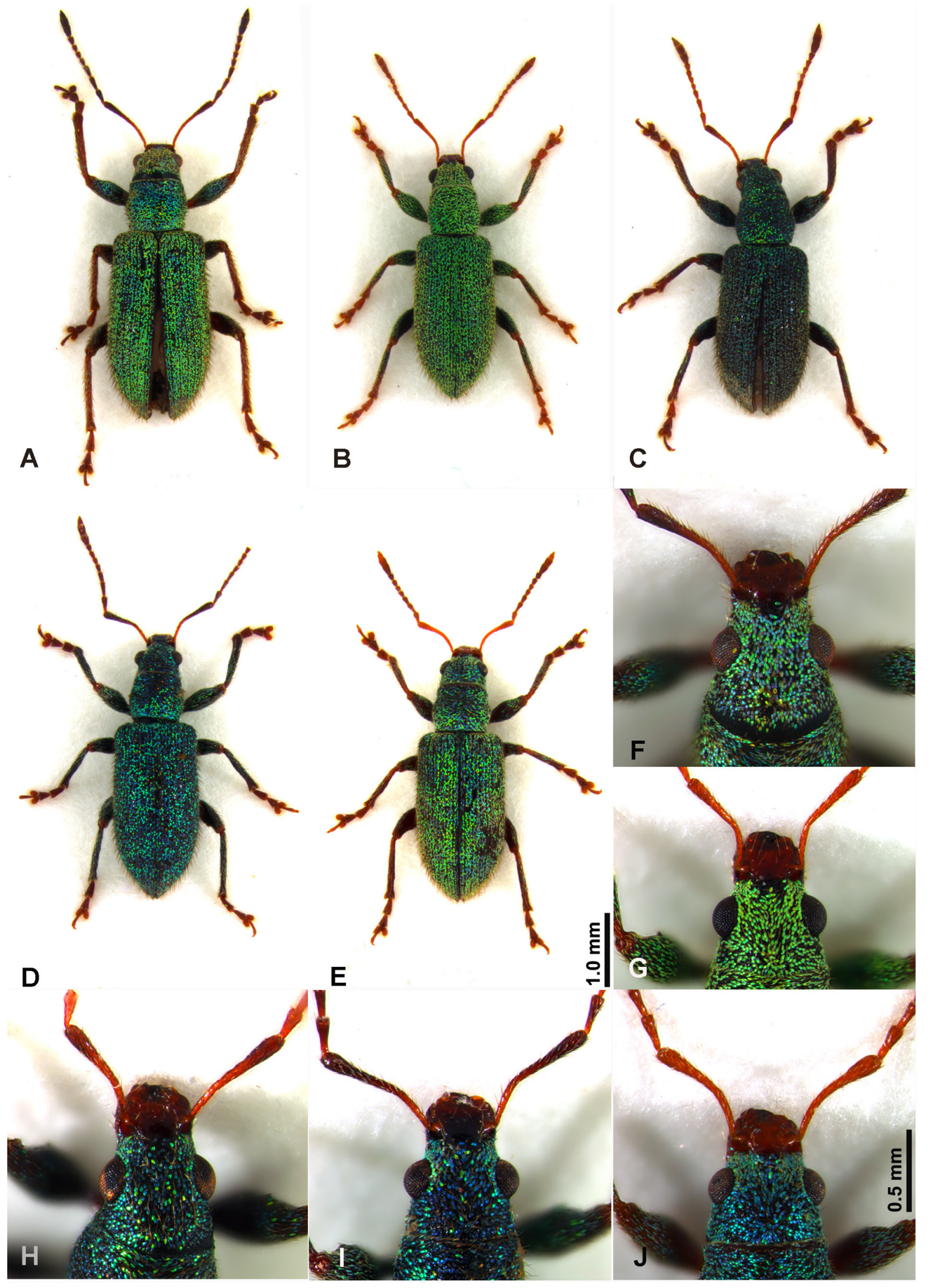

Fig. 1. A-E. Habitus. F-J. Head and antennal scape of Dichorrhinus spp., §. - A, F. D. alziari sp. nov., holotype. - B, G. D. creticus (Faust, 1889). - C, H. D. geiseri sp. nov., holotype. - D, I. D. korbi Schilsky, 1911. — E, J. D. pseudoscythropus Desbrochers, 1875. 


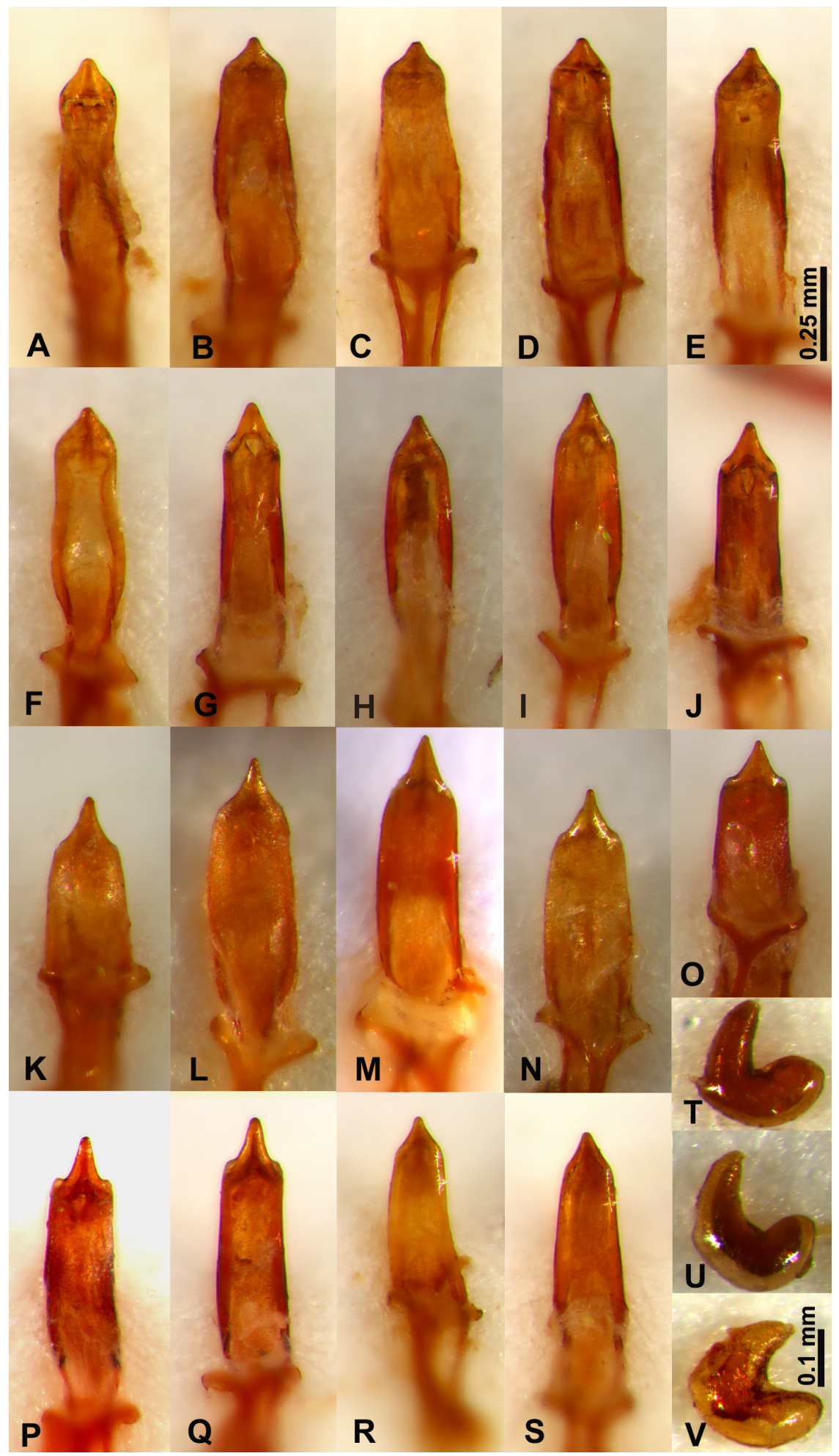

Fig. 2. A-F. Ventral view or aedeagus of Dichorrhinus geiseri sp. nov. A. Holotype. B-C. Denizli, Turkey. D-E. Fethyie, Turkey. F. Ören, Turkey. - G-J. Ditto of D. alziari sp. nov. G-I. Potami, Cyprus. J. Holotype. - K-O. Ditto of D. korbi Schilsky, 1911. K-L. Akseki, Turkey. M. Avlanbeli, Turkey. N. Davras, Turkey. O. Tahtali, Turkey. - P, Q. Ditto of D. creticus (Faust, 1889), Crete, Greece. - R-S. Ditto of D. pseudoscythropus Desbrochers, 1875, Sinfeh, Syria. - T-V. Spermatheca. T. D. geiseri sp. nov. U. D. alziari sp. nov. V. D. korbi, holotype. 
Elytra. (L/W) male: 1.9, female: 1.7, parallel-sided. Base much wider than pronotum. Shoulders well pronounced. Striae linear and regularly punctuate, interstriae slightly wider. Vestiture consisting of green-metallic, broad, roundish scales, straight cut at hind margin (nearly triangular), and long, semiraised, dark hairs. Scutellum longer than wide, rounded at tip.

LEGs. All femora strong, with sharp teeth varying in size, tibiae straight. Four visible tarsal segments, $1^{\text {st }}$ segment 1.4 times longer than $2^{\text {nd }}, 3^{\text {rd }}$ slightly shorter, about twice as wide, $4^{\text {th }}$ segment tiny and hardly visible, $5^{\text {th }}$ reaching as far as $1^{\text {st }}$. Claws fused at base, simple.

Male Genitalia (Fig. 2A-F). Sides of median lobe of aedeagus sinuate, apex with short and blunt (rounded) tip. Apodeme as long as median lobe. Tegmen with short parameres, tegminal apodeme straight, about half as long as apodeme of aedeagus. Ventrite 8 slightly curved, as long as aedeagus.

Female Genitalia. Ventrite 8 with very long and slender apodeme. Spermatheca with pointed, almost straight nodulus and strongly curved, globular cornu (Fig. 2T).

SeXual Dimorphism. Elytra of male parallel, widest at base, elytra pointed towards apex. Elytra of female widest at last third, rounded towards apex.

\section{Host plants}

The new species was collected in the phrygana plant association on Samos Island while beating and sweeping (M. Geiser, written communication), and while collecting in Turkey in steppe habitats mostly at higher altitudes (Fig. 3) (P. Białooki, written communication).

\section{Dichorrhinus alziari sp. nov. urn:Isid:zoobank.org:act:79295123-4A02-453E-A620-04F593058D01}

Figs 1A, F, 2G-J, U

\section{Etymology}

The new species is dedicated to the expert of the Curculionoidea-fauna of Cyprus, the former curator of the Muséum d'Histoire Naturelle de Nice and dear colleague Gabriel Alziar (Cassagnes-Bégonhès).

\section{Type material}

\section{Holotype}

đ, "sommet du Troodos (Limassol, Chypre), +/- $1900 \mathrm{~m}$; 10-V-2008" // "sur Juniperus foetidissima G. Alziar leg.”. Red label: "Holotype Dichorrhinus alziari sp. nov. C. Germann des. 2013” (NMBE).

\section{Paratypes}

$1 \uparrow$, same data as holotype (NMBE); $6 \hat{\jmath} \widehat{\partial}, 3$ 우 same data as holotype (cGA); $7 \hat{\jmath} \widehat{\partial}, 4 q q+$, "circuit

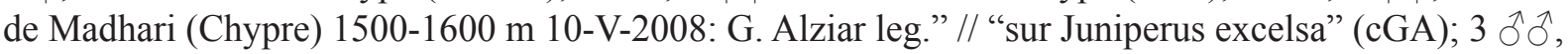

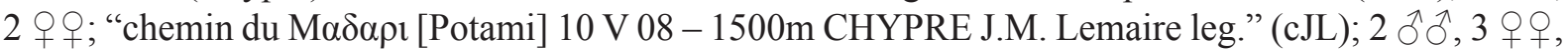
"Cyp. Troodos 1629 m. 24506 S. Doguet" (cJP). All 31 paratypes are additionally labelled with red paper: "Paratype Dichorrhinus alziari sp. nov. C. Germann des. 2013".

\section{Description}

SizE. (Without rostrum) males $4.7 \mathrm{~mm}(4.3-5.0 \mathrm{~mm})$, females $5.1 \mathrm{~mm}(4.7-5.5 \mathrm{~mm})$.

Colour. Body, head and femora dark brown to black; nasal plate, antennae, tips of femora, partly tibiae and all tarsal segments reddish-brown. 
HEAD. Eyes strongly convex, protruding, short oval in section. Rostrum about as long as wide, with well separated, glabrous and reddish-brown nasal plate; glossy from rostral dorsum to the scrobes. From there to epistome punctuate-striate. Head and basal half of rostrum with oval, green-metallic scales and long, partly bowed, dark hairs. Antennae reddish brown, apex of scape and club slightly darker. Antennal scape long, bowed and slender, reaching fore margin of pronotum. Apex of scape thickened, three times wider than base. Seven segments of antennal funiculus as follows (L/W): 1: 3.6, 2: 4.8, 3: 3.2, 4: 2.2, 5: 1.9, 6: 1.6, 7: 1.7. Club fusiform, long and slender.

Pronotum. (L/W): 0.9, transverse, widest in the middle, strongly constricted just before fore margin, sides rounded. Densely and irregularly punctuate on disc, vestiture consisting of oval, metallic green scales and long, dark, bowed hairs.

ELYTRA. (L/W) male: 2.0, female: 1.9, parallel-sided. Base much wider than pronotum. Shoulders well pronounced. Striae linear and regularly punctuate, interstriae slightly wider. Vestiture consisting of green-metallic, broad, roundish scales, straight cut at hind margin (nearly triangular), and long, semiraised, dark hairs. Scutellum longer than wide, rounded at tip.

LEGs. Femora not toothed, tibiae straight. Four visible tarsal segments, $1^{\text {st }}$ segment 1.4 times longer than $2^{\text {nd }}, 3^{\text {rd }}$ slightly shorter, about twice as wide, $4^{\text {th }}$ segment tiny and hardly visible, $5^{\text {th }}$ reaching as far as $1^{\text {st }}$. Claws fused at base, simple.

Male Genitalia. (Fig. 2G-J) Aedeagus slender, parallel sided to concave, apex obtuse angled and pointed. Apodeme as long as aedeagus. Tegmen with short parameres, tegminal apodeme straight, about half as long as apodeme of aedeagus. Ventrite 8 slightly curved, almost as long as aedeagus.

Female genitalia. Ventrite 8 with very long and slender apodeme. Spermatheca with pointed, slightly curved nodulus and strongly curved, globular cornu (Fig. 2U).

SEXUAL DIMORPHISM. See above.

\section{Host plants}

Alziar (2012) reported Juniperus excelsa and J. foetidissima as feeding plants of D. alziari sp. nov.

Dichorrhinus korbi Schilsky, 1911

Figs 1D, I, 2K-O, V

Dichorrhinus korbi Schilsky, 1911: Nr. 54 (description).

not Phyllobius squamosus korbi Schilsky, 1908: Nr. 48a [in Lona 1936: 491 (World catalogue); and in Weill et al. 2011 (faunistic list) as Dichorrhinus korbi Schilsky, 1908 (sic!)]

not Dichorrhinus korbi - Winkler 1924-1932: 1467 (Palaearctic catalogue). — Solari 1940: 76 (comparison in description). - Pesarini 1980: 206 (survey on Phyllobiini).

\section{Remark}

The description of Phyllobius squamosus korbi Schilsky, 1908, and the missing entry of the description of Dichorrhinus korbi in Lona (1936) caused an uncertainty about the year of description of $D$. korbi. However, this is corrected here. The label data (see below) of the holotype of D. korbi deposited in the NFM is in accordance with the description (Schilsky 1911). The examination of the holotype specimen, furthermore, revealed that the type is a female specimen, and not a male as written by Schilsky (1911) and repeated by Solari (1940). 


\section{Material examined}

\section{Holotype}

q, "Amasia [printed]" // "[illegible handwriting]" // "[perhaps a female sign (!), handwritten]" // "Korbi * Schils. [handwritten]". Red label: "Holotype Dichorrhinus korbi Schilsky, 1911 ett. Germann 2013" (MFN).

\section{Other material examined}

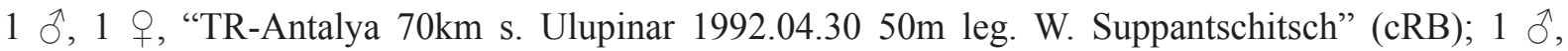
2 우우, “TR -vil Antalya 10.V.2001 Avlanbeli Pass 1120m 25 km S Elmali 3632 N 2959 E - S. Kadlec

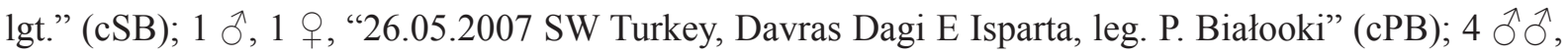

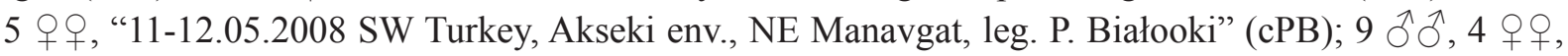
"24.05.2007 SW Turkey, Tahtali Dagi SW Kemer, leg. P. Białooki” (NMBE, cPB).

\section{Redescription}

SizE. (Without rostrum) males $4.5 \mathrm{~mm}(4.2-4.9 \mathrm{~mm})$, females $4.8 \mathrm{~mm}(4.6-5.3 \mathrm{~mm})$.

Colour. Body, head, femora and tibiae dark brown to black; nasal plate, antennae, tips of femora and basis of tibiae and all tarsal segments reddish-brown.

HEAD. Eyes strongly convex, very protruding, short oval in section. Rostrum about as long as wide, with well separated, glabrous and reddish-brown nasal plate, darkened in the middle; glossy from rostral dorsum to the scrobes. From there to epistome punctuate-striate. Head and basal half of rostrum with oval, green-metallic scales and long, partly bowed, dark hairs. Antennae reddish brown, second half of scape, partly funiculus and club slightly darker. Antennal scape long, bowed and slender, reaching fore margin of pronotum. Apex of scape thickened, three times wider than base. Seven segments of antennal funiculus as follows (L/W): $1: 3.0,2: 3.8,3: 2.7,4^{\text {th }}$ to $6^{\text {th }}: 2.0,7: 1.6$. Club fusiform, long and slender.

Pronotum. (L/W): 0.7, transverse, widest in the middle, strongly constricted just before fore margin, sides weakly rounded. Densely and irregularly punctuate on disc, vestiture consisting of oval, metallic green scales and long, dark, bowed hairs.

Elytra. (L/W) males: 2.1, females: 1.8, parallel-sided. Base much wider than pronotum. Shoulders well pronounced. Striae linear and regularly punctuate, interstriae slightly wider. Vestiture consisting of green-metallic, broad, roundish scales, rounded and partly cut at hind margin, and long, semi-raised, dark hairs. Scutellum longer than wide, rounded at tip.

Legs. Femora mostly with small, sharp teeth (at least meso- and metafemora). This character shows considerable variation in the examined specimens; teeth can also be completely reduced, tibiae straight. Four visible tarsal segments, $1^{\text {st }}$ segment 1.4 times longer than $2^{\text {nd }}, 3^{\text {rd }}$ slightly shorter, about twice as wide, $4^{\text {th }}$ segment tiny and hardly visible, $5^{\text {th }}$ reaching as far as $1^{\text {st }}$. Claws fused at base, simple.

Male Genitalia (Fig. 2K-O). Sides of median lobe of aedeagus parallel, apex with long, triangular and pointed tip. Apodeme as long as median lobe. Tegmen with short parameres, tegminal apodeme straight, about two thirds as long as apodeme of aedeagus. Ventrite 8 slightly curved, little shorter than aedeagus.

Female Genitalia. Ventrite 8 with very long and slender apodeme. Spermatheca with pointed, broad, curved nodulus and broad, strongly curved cornu (Fig. 2V).

SeXual Dimorphism. Same as above. 


\section{Diagnosis: key to the species of Dichorrhinus Desbrochers, 1875}

1. Elytra with shorter and adherent hairs. Scales on elytra elongate drop-shaped, green or brown to copper metallic, femora unarmed. Libya (Type locality: Cirene) ..freyi F. Solari, 1940

- Elytra with longer and semi-raised hairs. Scales on elytra more circular, green to greenish-bluish metallic

2. Head stout, rostrum very short. Eyes smaller, antennae and legs reddish brown and short, femora unarmed (Fig. 1E, J). Aedeagus short, conical, obtuse-angled and pointed at tip (Fig. 2R, S). Syria, Lebanon (Type locality: Djebel Baalbeck) .................................pseudoscythropus Desbrochers, 1875

- Rostrum longer. Eyes bigger and/or more bulged. Antennae and legs longer, at least femora darkened, and mostly at least metafemora toothed (remark: no teeth were found on femora of $D$. alziari sp. nov.; in $D$. geiseri sp. nov. there were always teeth varying from small and sharp to well pronounced and strong; in D. creticus and D. korbi there were all transitions from untoothed to small and sharp, toothed to strongly toothed)

3. Antennae reddish brown, eyes big, semi-circular, protruding (Fig. 1B, G). Apex of aedeagus with very long spine (Fig. 2P, Q). Greece: Crete Island (= type locality) creticus (Faust, 1889)

- Antennae darkened, eyes otherwise, aedeagus different

4. Eyes big, less than semi-circular, protruding, head as Fig. 1H. Aedeagus laterally constricted before apex. Apex with short and rounded (blunt) spine (Fig. 2A-F). Western Turkey, Greece: Samos Island (= type locality) geiseri sp. nov.

- Eyes smaller and strongly protruding (almost or distinctly semi-circular). Tip of aedeagus different (Fig. 2G-O)

5. Eyes protruding, distinctly semi-circular, slightly asymmetrically curved (Fig. 1D, I). Aedeagus broader, laterally slightly rounded, apex acute-angled and pointed (Fig. 2K-O). Turkey (Type locality: Amasia) korbi Schilsky, 1911

- Eyes protruding, less than semi-circular, symmetrically curved (Fig. 1A, F). Aedeagus slender, parallel-sided to concave, apex obtuse-angled and pointed (Fig. 2G-J). Cyprus (Type locality: Troodos Mts) alziari sp. nov.

\section{Further records}

The seasonally early-appearing species of Dichorrhinus are rarely collected and published data is scarce. Therefore, I add the following records, registered during examinations for the present study:

\section{Dichorrhinus pseudoscythropus Desbrochers, 1875}

Dichorrhinus pseudoscythropus Desbrochers, 1875: 9 (description).

\section{Material examined}

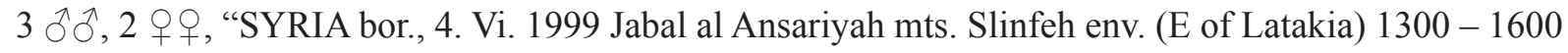
m a.s.l. S. Benedikt leg." (cSB, cRB).

\section{Remark}

A female syntype is depicted in Stüben et al. (2012) with the following label data (taken from photo): "Dichorrhinus pseudoscythro-pus Desb. [followed by a female sign] Syria: Djebel - Malbeck. Desbr. [handwritten]" (in coll. Heyden, SDEI). After L. Friedman (written communication 2012), the name Malbeck or Naalbec very likely refers to Baalbeck, nowadays a city in Lebanon. 
Dichorrhinus creticus (Faust, 1889)

Phyllobius creticus Faust, 1889: 92 (description).

\section{Material examined}

10 specimens, "GREECE, Crete Island, Chania, E-Chora Sfakion, Gorge, N35 12 '22" / E2407'36", "140m, 10.4.2012, leg. C. Germann"; 6 specimens, "GREECE, Crete Island, Chania, E-Chora Sfakion, Imbros Gorge, N35²' $2^{\prime} 35^{\prime \prime} /$ E2410'13", 170 m, 10.4.2012, leg. C. Germann” (cCG, NMBE).

\section{Dichorrhinus freyi $\mathrm{F}$. Solari, 1940}

Dichorrhinus freyi Solari, 1940: 74-76 (description).

\section{Material examined}

\section{Holotype}

§, "Cirene (Lyb.) IV. [19]38, G.Frey" // "Type [red label]" // "Dichorrhinus Freyi [male sign] holotypus ! m. det. F. Solari” (NMB).

\section{Paratypes}

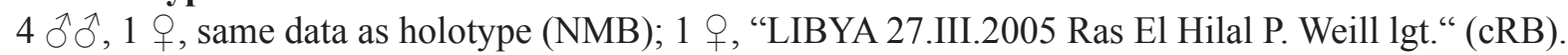

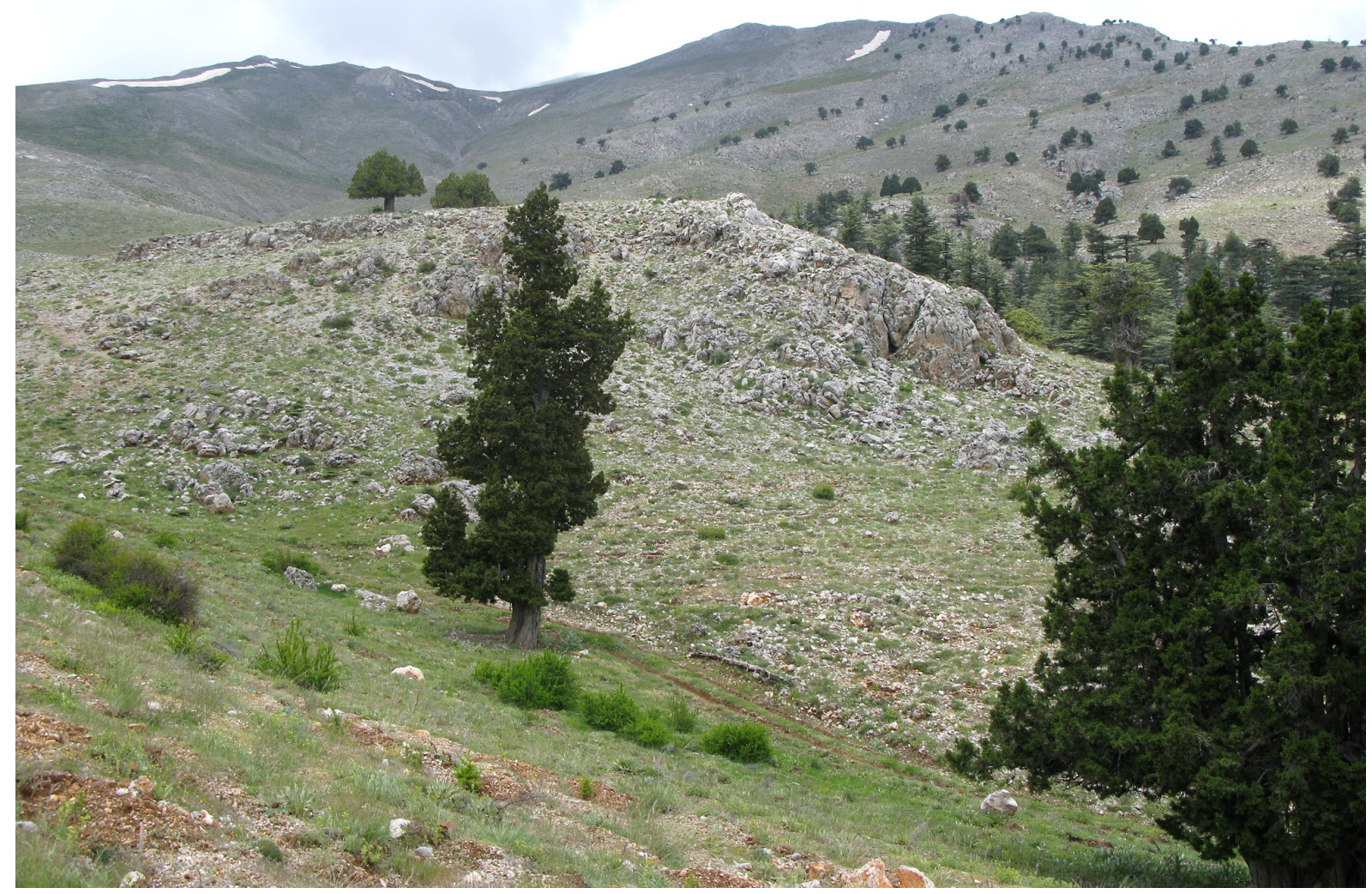

Fig. 3. Habitat of Dichorrhinus geiseri sp. nov. in May in Ören, Turkey at 2421 m. a. s. 1. (photo: P. Białooki). 
GERMANN C., A review of Dichorrhinus, with description of two new species

\section{Discussion}

Dichorrhinus geiseri sp. nov. from Western Turkey and Greece is similar to D. creticus based on the big eyes, and to $D$. korbi and $D$. alziari sp. nov. based on the habitus. Concerning the male genitalia, $D$. geiseri is the only species of the genus with a laterally constricted median lobus and a blunt tip. Dichorrhinus alziari sp. nov. is similar to $D$. korbi based on its habitus; however, the head shape and the tip of the aedeagus are different.

The species $D$. creticus, $D$. korbi, $D$. geiseri sp. nov., and $D$. alziari sp. nov., seem to represent a closer related group (creticus species-group) within Dichorrhinus based on the morphological characters examined, whereas $D$. pseudoscythropus, with a stout head, short and reddish brown antennae and legs, and $D$. freyi, with short and adherent hairs on elytra and an apparent colour dimorphism, stand apart.

The most widespread species are Dichorrhinus korbi, with seven localities in Turkey, and D. geiseri sp. nov., which is presently known from five localities in Greece (Samos Island) and Western Turkey (Fig. 4). Interestingly, their distribution areas overlap in Western Turkey. D. pseudoscythropus is known from Syria and Lebanon. D. alziari is endemic to Cyprus, D. creticus is endemic to Crete Island and D. freyi is known from two localities at the coast of Libya.

Some insights into the species' biology as adults can furthermore be provided. Dichorrhinus creticus was observed in spring (April) on Crete Island (Chora Sfakion) feeding on Cupressus sempervirens trees

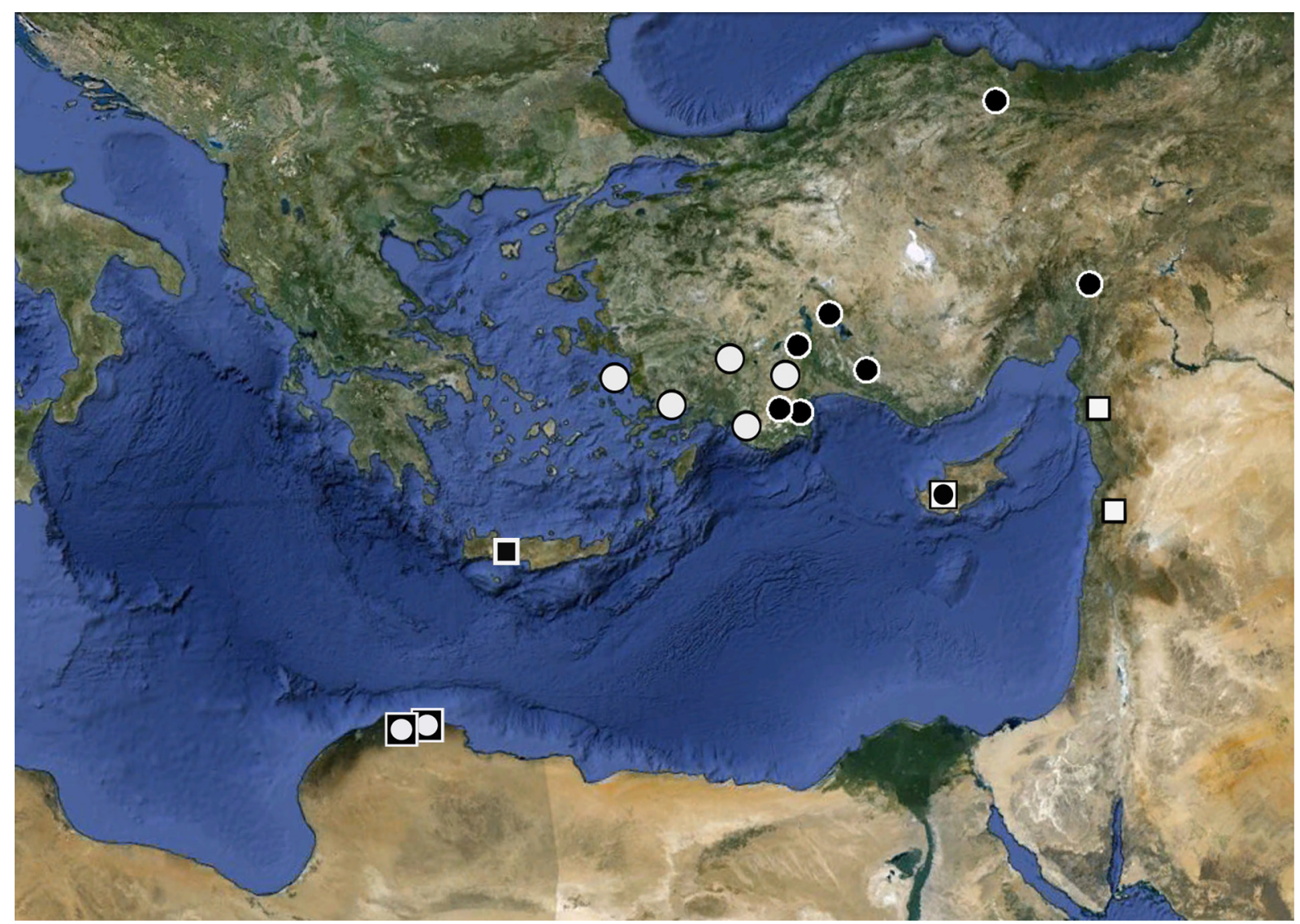

Fig. 4. Distribution areas of Dichorrhinus spp. White circle: Dichorrhinus geiseri sp. nov. Black circle: Dichorrhinus korbi Schilsky, 1911. Black square: D. creticus (Faust, 1889). White square with black circle: D. alziari sp. nov. White square: D. pseudoscythropus Desbrochers, 1875. Black square with white circle: D. freyi Solari, 1840. (Copyright 2012 Google) 
(Fig. 5). Alziar (2012) mentions Juniperus excelsa and J. foetidissima for Dichorrhinus alziari sp. nov. on Cyprus, and Białooki (written communication 2012) collected D. geiseri sp. nov. in steppe habitats where Cupressaceae grew (Fig. 3). It is likely that the other species can also be found on similar trees of Cupressaceae.

\section{Acknowledgements}

I am thankful to Gabriel Alziar (France, Cassagnes-Bégonhès), Stanislav Benedikt (Czech Republic, Pilsen), Piotr Białooki (Poland, State Plant Health and Seed Inspection Service, Border Division Gdynia), Roman Borovec (Czech Republic, Sloupno), Michael Geiser (Switzerland, Basel), Jean-Michel Lemaire (France, Contes), Jean Pelletier (France, Monnaie) and Joachim Willers (MFN) for the loan of specimens for study. I am grateful to Laibale Friedman (Israel, Department of Zoology, The George S. Wise Faculty for Life Sciences, Tel Aviv University) for his support in interpreting the label data, and to two referees for their constructive critisism. Piotr Białooki kindly provided a habitat photo.

\section{References}

Alonso-Zarazaga M.A. \& Lyal C.H.C. 1999. A World Catalogue of Families and Genera of Curculionoidea (Insecta: Coleoptera). (Excepting Scolytidae and Platypodidae). Entomopraxis, Barcelona.

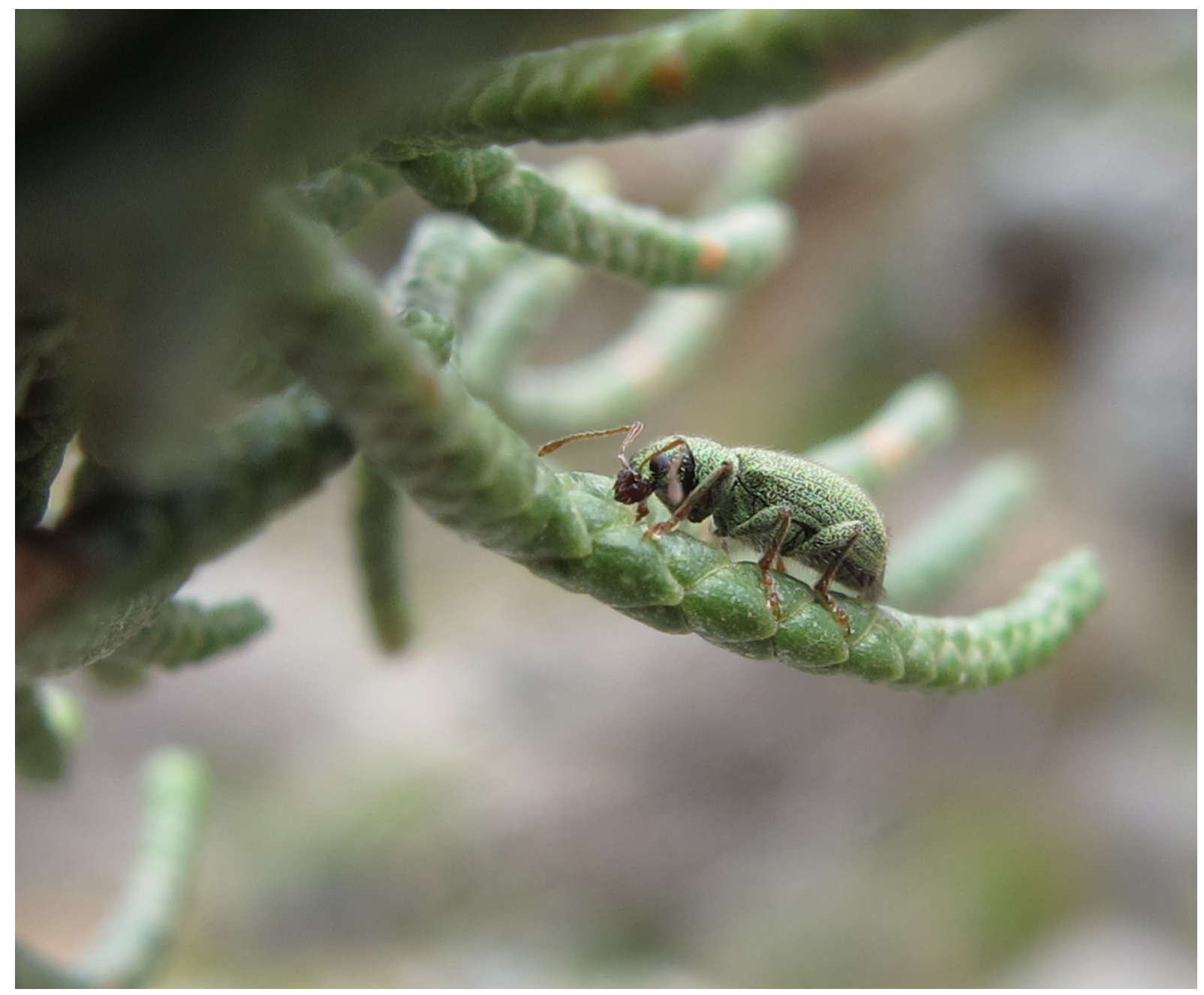

Fig. 5. Dichorrhinus creticus in April on Cupressus sempervirens, Chora Sfakion, $140 \mathrm{~m}$ a. s. 1., Crete Island, Greece (photo: C. Germann). 
GERMANN C., A review of Dichorrhinus, with description of two new species

Alziar G. 1995. Contribution à la connaissance de l'Histoire Naturelle de l'île de Chypre (Coleoptera: Curculionidae I). Biocosme Mésogéen 12 (2/3): 65-82.

Alziar G. 2003. Contribution à la connaissance de l'Histoire Naturelle de l'île de Chypre (Coleoptera: Curculionoidea III). Biocosme Mésogéen 20 (1): 51-53.

Alziar G. 2012. The Curculionoidea-Fauna of Cyprus. Catalogues \& Keys No. 3. http://www.curci.de/ illustrated_catalogue/curculionoidea-fauna_of_cyprus/ (accessed 27th October, 2012).

Desbrochers des Loges M.J. 1875. Diagnoses de Curculionides inédits. Opuscules entomologiques 1, J. Desbrochers Des Loges, Paris.

Desbrochers des Loges M.J. 1902a. Révision des Curculionides de la faune Européenne et circameditérranéenne en Afrique et en Asie, appartenant au Groupe des Scythropidae. Le Frelon 10 (9): 137-144.

Desbrochers des Loges M.J. 1902b. Révision des Curculionides de la faune Européenne et circameditérranéenne en Afrique et en Asie, appartenant au Groupe des Scythropidae. Le Frelon, 10 (10): 145-158.

Lona C. 1936. Curculionidae: Otiorrhynchinae I. In: S. Schenkling (ed.), Coleopterorum Catalogus. W. Junk, The Hague.

Pesarini C. 1980. Le specie paleartiche occidentali della tribu Phyllobiini (Coleoptera, Curculionidae). Estratto dal Bolletino di Zoologia agraria e di Bachicoltora Serie II 15: 49-230.

Schilsky J. 1908. Die Käfer Europas. Nach der Natur beschrieben von Dr. H. C. Küster und Dr. G. Kraatz. XLV: Nr. 48. Verlag von Bauer und Raspe. Nürnberg.

Schilsky J. 1911. Die Käfer Europas. Nach der Natur beschrieben von Dr. H. C. Küster und Dr. G. Kraatz. XLVII: Nr. 54. Verlag von Bauer und Raspe. Nürnberg.

Solari F. 1940. Sette nuovi Curculionidi della Libia ed alcune note sui Ritirinini. Memorie della Società entomologica Italiana 19: 70-92.

Stüben P.E., Sprick P., Behne L., Alziar G., Colonnelli E., Giusto C., Messutat J. \& Teodor L.A. 2012. The Curculionoidea of Cyprus. Results of a collecting journey on Cyprus by members of the CurculioInstitute in April 2010. Snudebiller 13: 80-137.

Weill P., Pelletier J., Benedikt S. \& Kresl P. 2011. Liste des charançons collectés en Syrie durant trois années complètes et plusieurs excursions entre 1999 et 2004 - base pour un futur catalogue (Coleoptera, Curculionoidea). Weevil News 66: 1-25. http://www.curci.de/weevilnews/no/66/

Winkler A. 1924-1932. Catalogus Coleopterorum Regionis Palaearcticae. Albert Winkler Verlag, Wien.

Manuscript received: 24 January 2013

Manuscript accepted: 18 May 2013

Published on: 7 June 2013

Topic editor: Koen Martens

Desk editor: Kristiaan Hoedemakers

Printed versions of all papers are also deposited in the libraries of the institutes that are members of the EJT consortium: Muséum National d'Histoire Naturelle, Paris, France; National Botanic Garden of Belgium, Meise, Belgium; Royal Museum for Central Africa, Tervuren, Belgium; Natural History Museum, London, United Kingdom; Royal Belgian Institute of Natural Sciences, Brussels, Belgium; Natural History Museum of Denmark, Copenhagen, Denmark. 